\title{
Africa's Destiny and Higher Education Transformation
}

\author{
Barnabas Nawangwe
}

\section{Introduction}

Africa, the cradle of mankind and civilization, presents the best example of a people falling from the most culturally and technologically advanced society to the most backward and marginalized. While other ancient civilizations like China, Babylon, and India either transformed and survived or persisted in the case of China, the Egyptian civilization was destroyed and was never to recover. The University of Sankore at Timbuktu, established in the 13th century and recognized by many scholars as one of the oldest universities on earth, is testimony to the advancement in scholarship that Africa had attained before any other civilization. But that is all history. Instead, Africa remains the most marginalized continent, viewed by many as a hopeless sleeping giant without any hope for awakening and moving forward as part of a modern global society.

Different parts of Africa were conquered by different civilizations, and their influence implanted to varying degrees. Little is known about scholarship between the time of the fall of the Egyptian Empire and the era of colonialism. However, Africa still boasts of some of the oldest existing universities, including the University of Karueein, founded in 859 AD in Fez, Morocco. Outside the Maghreb, all universities are modern-day creations of the colonial powers which subdued Africa as early as the 15 th century.

\footnotetext{
B. Nawangwe ( $\varangle)$

Makerere University, Kampala, Uganda

e-mail:vc@admin.mak.ac.ug 


\section{The Colonial African University}

No other place on earth has been raped and humiliated like Black Africa. All precious resources have over the centuries been shipped out of the Continent for close to no compensation. Even the people themselves were herded into slavery with the connivance of Africa's greedy rulers of the time. With all these injustices perpetrated on the Continent, it is surprising that some people wonder why Africa is such a huge landmass with inherent inertia. But not all is lost.

The colonists established training institutions at the very basic level, which were eventually to grow into universities. Makerere University in Uganda is a good example of such a colonial university. Founded as a small vocational school in 1922 by the British colonial government in Uganda, Makerere would eventually become the country's lone institution of higher education. The aim was to build a technical school for the indigenous Africans, obviously to serve the needs of the growing European population. The first class of fourteen students, seven enrolled in carpentry and seven enrolled in auto mechanics, began their training towards the end of 1922. All the fourteen students were men, and the school's motto was 'Let Us Be Men'.

British governor Philip Mitchell (1935-1940) proposed moving Makerere beyond vocational training and expanding it to become the centre for higher education in British East Africa (Kenya, Tanganyika, and Uganda), and in 1937 Makerere began to offer post-high school certificates. Other certificate courses were introduced to satisfy the demands of the migrant European community, including nursing and agriculture. It is clear that the intention of the colonists was to provide semi-skilled labour for the consolidation of their power. In 1949, the University of London affiliated with Makerere, just as it did with similar schools in sub-Saharan Africa, including Ibadan, Accra and Lagos. As the colonies became more advanced, the colonial governments needed more advanced skills to serve their interests, and in 1963 courses taken at Makerere could count toward a degree at the University of London, and its students were listed as graduates of the British institution. But while these developments helped the colonists exploit the colonies better, they also created a critical mass of enlightened Africans who would start agitating for the independence of their countries.

\section{The Emergence of National Universities}

After attaining independence, African countries desired to reduce dependence on their colonial masters for the production of much needed human resources. The colonial university was designed to produce middle carder technical personnel and officers to help the colonial government in administration. Very little attention had been given to producing human resources to manage industrialization processes, which the young independent countries felt was crucial to the consolidation of their independence. By 1970, Makerere became the independent university of the Republic 
of Uganda, offering both undergraduate and postgraduate courses toward its degree programs. Similar universities were established at Nairobi, Dar es Salaam and other African capitals. The University was seen by the young independent African countries as an essential ingredient of national pride and independence. Indeed, professors at Makerere University, for example, were paid higher than Ministers of Government, causing unease among some of the ministers.

In Ronald Bisaso's article in the book 'Flagship Universities of Africa', Bisaso (2017) states that '[s]uch universities were established as both national and regional symbols with the main objective of human resource capacity development. Makerere University transformed from a colonial university to a nationalist university'. The new national universities were gems in their countries, and they enjoyed enormous influence, and resources were unlimited. The students were practically paid to study, and because of their small numbers, all of them left university to find well-paying jobs waiting for them. It was time for the independent countries to demonstrate full independence. Even in the area of scholarship, new programs were introduced to train critical human resources for the countries' development. The new programs included engineering, human and veterinary medicine, agriculture, law, and business studies. However, the university was still viewed mainly as a place for human resource training.

In many African countries, the two decades which followed independence were characterized by strife and very little development. This pushed Africa further down the drain of marginalization. When the guns finally went silent, the African countries were heavily indebted, and the World Bank practically ran their economies and dictated their development agendas. I will not tire in decrying the disastrous structural adjustment programs of the World Bank, which brought African universities to their knees. It took almost two decades for the World Bank to realize that their assertion that higher education was a private good was causing untold damage to universities in Africa. By this time, African universities had entered the era of so-called neo-liberalism. According to Bisaso (2017): 'The era of the neoliberal university triggered considerable expansion of higher education institutions differentiated by type and ownership'. Governments created new public universities to try and address the high demand, and the higher education sector was liberalized, leading to the mushrooming of private institutions. New academic programs were introduced as a way of increasing revenue and responding to market demands, with little regard for quality.

\section{Becoming Research-Intensive Universities}

The tremendous success of the so-called Asian Tigers, which were at the same level of development as most sub-Saharan countries at the time of independence, sent a strong message to African universities. African universities could no longer thrive on the production of large numbers of graduates. They had to re-invent themselves. The society in which they are located started questioning their relevance. A few of 
the universities including Makerere, Nairobi and Dar es Salaam, Ghana and Ibadan embraced a culture of research with the support of international development agencies. It became increasingly clear that African universities had to undergo a paradigm shift.

Many scholars argue that Africa cannot continue hiding under the excuse of colonialism as the reason for lack of development. Universities are called upon to champion a new era in Africa's development agenda. Agenda 2063 and national development agendas require that African universities will lead the struggle to achieve the SDGs and position Africa on a clear path of development. And the universities are responding positively. Through regional organisations including the African Research Universities Alliance (ARUA), the Regional Universities Forum for Capacity Development in Agriculture (RUFORUM), the Consortium for Advanced Research Training in Africa (CARTA) and others, African research universities are beginning to address the insignificant contribution to global research, currently standing at 2\%. Former South African President Thabo Mbeki declared that Africa was undergoing a renaissance. That renaissance will not succeed without the critical involvement of Africa's universities, and finally African governments are coming along to appreciate this reality. Many of them have started funding universities to do research critical for national development. The recent COVID-19 pandemic has clearly demonstrated that Africa has to wake up or perish. The innovations that have come out of African universities are a clear sign that African universities have the capacity to turn around the Continent's fortunes.

\section{Conclusion}

For more than 1500 years, Africa has suffered humiliation and marginalization. Africa's weakness is mainly attributed to lack of knowledge and knowledge institutions, but a new era is dawning on Africa. Are African universities the engine that will propel this great continent ahead? The answer is certainly YES.

\section{Reference}

Bisaso, R. (2017). Makerere University as a Flagship Institution: Sustaining the Quest for Relevance. In D. Teferra (Ed.), Flagship Universities of Africa (pp. 425-466). Palgrave Macmillan.

Barnabas Nawangwe has been the Vice-Chancellor of Makerere University, one of the oldest and premier universities in Africa, since August 2017. Prior to that, he was Deputy Vice-Chancellor, Dean and Principal of the College of Engineering, Head of the Department of Architecture, all at Makerere. He is a member of several international professional organisations and has overseen the academic and administrative transformation of Makerere University, including her transformation from a faculty-based to a collegiate University. 
Open Access This chapter is licensed under the terms of the Creative Commons Attribution 4.0 International License (http://creativecommons.org/licenses/by/4.0/), which permits use, sharing, adaptation, distribution and reproduction in any medium or format, as long as you give appropriate credit to the original author(s) and the source, provide a link to the Creative Commons license and indicate if changes were made.

The images or other third party material in this chapter are included in the chapter's Creative Commons license, unless indicated otherwise in a credit line to the material. If material is not included in the chapter's Creative Commons license and your intended use is not permitted by statutory regulation or exceeds the permitted use, you will need to obtain permission directly from the copyright holder. 